\title{
Delineating the Diversity of Spinal Interneurons in Locomotor Circuits
}

\author{
Simon Gosgnach, ${ }^{1}$ Jay B. Bikoff, ${ }^{2}$-Kimberly J. Dougherty, ${ }^{3}$ Abdeljabbar El Manira, ${ }^{4}$ @Guillermo M. Lanuza, ${ }^{5}$ \\ and Ying Zhang ${ }^{6}$ \\ ${ }^{1}$ Department of Physiology, University of Alberta, Edmonton, Alberta T6G 2H7, Canada, ${ }^{2}$ Department of Neuroscience, Columbia University, New York, \\ New York 10032, ${ }^{3}$ Department of Neurobiology and Anatomy, Drexel University, Philadelphia, Pennsylvania 19129, ${ }^{4}$ Department of Neuroscience, \\ Karolinska Institutet, Stockholm SE-171 77, Sweden, ${ }^{5}$ Department of Developmental Neurobiology, Fundacion Instituto Leloir, Buenos Aires C1405BWE, \\ Argentina, and ${ }^{6}$ Department of Medical Neuroscience, Dalhousie University. Halifax, Nova Scotia B3H 4R2, Canada
}

Locomotion is common to all animals and is essential for survival. Neural circuits located in the spinal cord have been shown to be necessary and sufficient for the generation and control of the basic locomotor rhythm by activating muscles on either side of the body in a specific sequence. Activity in these neural circuits determines the speed, gait pattern, and direction of movement, so the specific locomotor pattern generated relies on the diversity of the neurons within spinal locomotor circuits. Here, we review findings demonstrating that developmental genetics can be used to identify populations of neurons that comprise these circuits and focus on recent work indicating that many of these populations can be further subdivided into distinct subtypes, with each likely to play complementary functions during locomotion. Finally, we discuss data describing the manner in which these populations interact with each other to produce efficient, task-dependent locomotion.

Key words: CPG; development; interneuron; locomotion; spinal cord

\section{Introduction}

City dwellers on their way to work, wildebeests migrating through the Serengeti, and ocean-dwelling sea slugs escaping the predatory starfish all have one thing in common: their ability to move actively in space or locomote. For more than a century, it has been known that neural circuits, referred to as locomotor central pattern generators (CPGs), are the source of the basic locomotor rhythm and pattern. Several studies have demonstrated that these neural circuits reside in the ventral aspect of the spinal cord (Grillner and Wallen, 1985; Grillner et al., 1998; Kiehn, 2016). Although the basic left-right and flexor-extensor alternations that underlie locomotion might appear straightforward, the core elements of movement can be expressed in different forms depending on behavioral context. For example, as the speed of quadrupedal locomotion increases from a walk to a trot to a gallop, the synergy between muscles on the left and right sides of the body seamlessly transition from alternation (walking) to coactivation (galloping) (Bellardita and Kiehn, 2015; Lemieux et al., 2016). Similarly, while walking on a narrow rocky path, stride length is modified constantly to optimize foot placement and avoid obstacles. Whether the input to achieve these modifications originates from the cortex or the peripheral afferents, the loco-

\footnotetext{
Received Aug. 21, 2017; revised Sept. 27, 2017; accepted 0ct. 11, 2017.

The authors declare no competing financial interests.

Correspondence should be addressed to Simon Gosgnach, Department of Physiology, University of Alberta, 3-020D Katz Building, University of Alberta, Edmonton, Alberta T6G 2H7, Canada, E-mail: gosgnach@ualberta.ca; or Ying Zhang, Department of Medical Neuroscience, Dalhousie University, Life Sciences Research Institute, 1348 Summer Street, Halifax, Nova Scotia, Canada B3H 4R2. E-mail: ying.zhang@dal.ca.

DOI:10.1523/JNEUROSCI.1829-17.2017

Copyright $\odot 2017$ the authors $\quad 0270-6474 / 17 / 3710835-07 \$ 15.00 / 0$
}

motor CPGs require a high degree of flexibility to integrate this information and generate smooth, task-dependent output (El Manira, 2014; Grillner and El Manira, 2015).

The ability of the locomotor CPGs to generate versatile outputs is linked to the diversity of its component neurons and their pattern of connectivity. Studies aimed at identifying the interneuronal components of the locomotor CPGs as well as the manner in which they interact began in the mid-1900s. Initially, this work was performed using a physiological approach, recording blindly from cells in the spinal cord, investigating their activity during locomotion, and characterizing them based on their anatomical features and/or the afferent input they received (for review, see Jankowska, 1992, 2001). This work, which was primarily performed in the cat, identified potential component interneurons of the locomotor CPGs, but provided limited information on how they might interact with one another and was not amenable to studying their function during locomotion. Subsequent work in lamprey and Xenopus has provided important insights into the organization of the locomotor CPGs (Grillner, 2003; Roberts et al., 2010).

Since the turn of the century, classic physiological techniques have been combined with molecular genetic approaches to identify cells based on their expression of specific transcription factors. Early in embryogenesis, the graded activity of diffusible morphogens (i.e., Sonic hedgehog, bone morphogenic proteins, and Wnts) along the dorsal-ventral axis of the neural tube delineates the expression of specific transcription factors, creating distinctive progenitor domains. These domains produce 11 cardinal interneuron classes in the spinal cord ( $\mathrm{dI} 1-\mathrm{dI} 6, \mathrm{~V} 0-\mathrm{V} 3)$ and the motoneurons (Goulding and Pfaff, 2005; Alaynick et al., 2011; 
Catela et al., 2015). Identification of the specific transcription factor profiles of each neuronal population have allowed groups of molecularly related cells in the spinal cord to be targeted and characterized reliably (Jessell, 2000; Goulding, 2009; Grillner and Jessell, 2009; Arber, 2012).

The ventral spinal cord, the region housing the primary components of the locomotor CPGs, harbors at least five of these interneuronal populations: V1 (En1-expressing) and V2 (Chx10/ Gata3-expressing) neurons that project ipsilateral axons; the V0 and V3 neurons, which primarily project commissural axons and are marked by the transcription factors Dbx1 and Sim1, respectively; and the dorsally derived dI6 interneurons (Dmrt3- and/or Wt1-expressing), which possess ipsilateral and contralateral axons. Over the past two decades, experimental evidence has demonstrated that a significant proportion of the aforementioned populations are rhythmically active during locomotion and the ablation/silencing of several of these cell groups resulted in specific movement deficits suggestive of a definable function during locomotion.

As the acuity of techniques used to investigate the primary classes of interneurons has improved, it has become clear that there is significant cell-type heterogeneity within many of the cardinal populations that were initially identified and they can be further subdivided based on genetic marker expression downstream of the transcription factors originally used to define each group. Although it is known that postmitotic differentiation involves a series of spatially and temporally regulated transcription factor cascades (Tripodi and Arber, 2012; Lu et al., 2015), the precise molecular mechanisms responsible for generating diversity within each cardinal population are poorly understood. Despite this, distinct differences in the characteristics of each subset, as well as their specific function during locomotion, are starting to emerge and indicate that recruitment of the appropriate subtypes at any given time may hold the key to the versatility of the locomotor CPGs. In this review, we focus on the genetic variability contained within each of the genetically defined interneuronal populations and discuss recent findings regarding their functional role and synaptic connectivity.

\section{Ipsilaterally projecting interneuronal populations}

Three essential features of hindlimb locomotion are: (1) generation of rhythmic locomotor activity, (2) precise coordination of motoneurons innervating antagonistic (flexor-extensor) musculature on the ipsilateral side of the spinal cord, and (3) appropriate coordination of motoneurons on the contralateral sides of the spinal cord (Kiehn, 2006). Studies in which locomotor activity was evoked in the midline-transected spinal cord demonstrated that, although contralateral coordination was abolished, rhythmic locomotor activity persisted, as did appropriate coordination between flexor and extensor motoneurons (Kjaerulff and Kiehn, 1996; Cowley and Schmidt, 1997; Cangiano and Grillner, 2005; see also Moult et al., 2013). This work indicates that generation of the basic locomotor rhythm, as well ipsilateral flexor-extensor coordination, rely on interneurons that project their axons ipsilaterally. Two groups of ventrally located spinal interneurons, the $\mathrm{V} 1$ and V2 populations, have been shown to project in an exclusively ipsilateral manner.

The first of the ipsilaterally projecting populations to be characterized was the V1 class of interneurons (Burrill et al., 1997; Saueressig et al., 1999). Initial investigation indicated that they were inhibitory in nature (Higashijima et al., 2004; Li et al., 2004). Based on their connectivity and response to sensory stimulation, it was demonstrated that the functionally defined Renshaw cells and a substantial portion of the Ia reciprocal interneurons are contained within the V1 population (Sapir et al., 2004; BenitoGonzalez and Alvarez, 2012; Stam et al., 2012). Both of these cell types are rhythmically active during locomotion, but they are not thought to be essential components of the locomotor CPGs because stepping is unaffected after their silencing (McCrea et al., 1980; Pratt and Jordan, 1980; Enjin et al., 2017). Importantly, Renshaw cells and Ia inhibitory interneurons constitute only a small fraction of the entire V1 population, which underscores the diversity within this cell group. Renshaw cells arise from the very first wave of neurogenesis of V1 interneurons, between embryonic days 9 and 10 (Benito-Gonzalez and Alvarez, 2012; Stam et al., 2012). The differentiation and maintenance of Renshaw cell identity is regulated temporally by the expression of a series of transcription factors, including Foxd3, Oc1, Oc2 and MafB, whereas Ia inhibitory interneurons express Foxp2 (Stam et al., 2012). The function of the entire V1 population during locomotion was assessed via selective silencing of these cells, which resulted in a drastic reduction of locomotor speed, implicating the $\mathrm{V} 1$ population in the regulation of locomotor frequency (Gosgnach et al., 2006). Interestingly, this slowing occurred without any ipsilateral coordination defects; however, when a subset of the $\mathrm{V} 2$ population (the ipsilaterally projecting V2b interneurons) were ablated together with the V1 population, ipsilateral flexor-extensor coordination breaks down (Zhang et al., 2014), suggesting that the inhibitory interneurons mediating flexor-extensor alternation are derived from multiple cardinal interneuron classes.

Although no genetic markers have been identified that allow us to distinguish between the V1 cells involved in regulating locomotor speed and those involved in ipsilateral coordination, molecular profiling of the V1 cells suggests that we are likely scratching the surface when it comes to the diversity within this population. Recent work has identified 19 transcription factors with combinatorial expression in the V1 population that provides an inordinate degree of molecular diversity within this interneuron class (Bikoff et al., 2016; Gabitto et al., 2016). Consistent with the hypothesis that genetic identity is linked to function, these studies demonstrate that different V1 subsets exhibit distinct physiological signatures and occupy highly stereotyped positions within the spinal cord that appear to constrain the nature of synaptic input to these interneurons. Moreover, anatomical and physiological experiments indicate the existence of variant inhibitory circuit architecture for V1 interneurons controlling hip-, ankle-, and foot-innervating motor pools, perhaps reflecting different biomechanical properties of individual muscles (Bikoff et al., 2016). Interestingly, the precise identity of these cell types varies along the rostrocaudal axis, where limb and thoracic differences emerge through a Hox-dependent mechanism analogous to that which controls motoneuron differentiation (L. Sweeney, unpublished observations).

The V2 population emerge from Lhx3-expressing progenitor cells and can be divided into two subsets, V2a and V2b interneurons, through mechanisms involving Notch/Delta signaling and the transcription factors Foxn4, Tal1, and Lmo4 (Peng et al., 2007; Kimura et al., 2008; Joshi et al., 2009, Del Barrio et al., 2013, Li et al., 2005). Unlike V1 interneurons, which are thought to be exclusively inhibitory, the V2 population consists of the GABAergic/ glycinergic V2b neurons that express Gata2/3, as well as excitatory V2a cells that express Chx10 (Lundfald et al., 2007; Peng et al., 2007). These two subsets are born simultaneously in a mosaic manner during early postmitotic neurogenesis (Joshi et al., 2009, Del Barrio et al., 2013). Although the role of the V2b cells in ipsilateral flexor-extensor alternation has come to light 
recently (see above), the V2a cells were the first subset of this population to be characterized and shown to be involved in left right alternation (Crone et al., 2008; Crone et al., 2009). This was demonstrated to be due to their axonal projection onto a population of commissural interneurons, the V0 cells, which regulate contralateral motoneuron activity during locomotion (Lanuza et al., 2004; Crone et al., 2009). Recent work has demonstrated that further diversity exists within V2a interneurons and that a portion of these cells may be involved in locomotor rhythm generation (Eklöf-Ljunggren et al., 2012; Ljunggren et al., 2014).

Identification of locomotor rhythm-generating cells has been a priority since the initial demonstration that transcription factor expression could be used to divide the spinal cord into functionally related populations. In the years since, all of the known ipsilaterally projecting, excitatory cell populations have been genetically silenced or ablated individually with no effect on the ability of locomotor activity to be generated. There are several possible reasons why rhythm generating neurons were not captured in these experiments. First, there may be no single population of rhythm-generating cells. Instead, many neurons may be capable of performing this function and have the capacity to compensate for the loss of any rhythm-generating cells. Another possibility is that the rhythm-generating neurons do not belong to a single cardinal class, but rather are composed of subsets of several classes. Data from the Shox2 neurons support this latter hypothesis. Shox 2 is expressed postmitotically in a subset of the V2a cells and several interneuronal populations in the dorsal spinal cord. Silencing of all Shox2 neurons decreased the locomotor frequency; however, selective ablation of Shox $2+$ V2a interneurons had no effect on the rhythm (Dougherty et al., 2013). This suggests that the non-V2a subset of Shox 2 neurons contributes to rhythm generation. Importantly, the fact that ablation of these neurons did not result in the cessation of locomotor activity indicates that other cell types must also be involved in rhythm generation.

In contrast to the work in mouse, direct evidence for a role in the control of locomotor rhythm generation, as well as the functional diversity of the V2a population, comes from studies investigating the locomotor CPGs that control swimming in zebrafish. The excitatory drive within these CPGs originates from the V2a subset of interneurons (Kimura et al., 2006), which are necessary and sufficient for the generation of the locomotor rhythm (EklöfLjunggren et al., 2012; Ljunggren et al., 2014) and active during locomotion in a speed-dependent manner (McLean et al., 2008, 2009). The functional diversity of the V2a interneurons is paramount because it has been shown that they can be segregated into three functionally distinct subclasses that become activated at specific locomotor speeds (slow, intermediate, or fast; Ausborn et al., 2012). Furthermore, interneurons belonging to each subclass make selective monosynaptic connections to drive the activity of motoneurons recruited at the same locomotor speed, thereby forming a modular locomotor CPG with three separate microcircuits underlying slow, intermediate, or fast locomotion (Gabriel et al., 2011; Kyriakatos et al., 2011; Ampatzis et al., 2013, 2014). Traditionally, the generation of the locomotor rhythm has been considered to rely on interneurons without contribution from motoneurons. Recent evidence now shows that motoneurons strongly influence the activity of the locomotor CPGs and can regulate the frequency of locomotion. In zebrafish, this is mediated via gap junctions that allow retrograde control of the strength of the excitatory drive within the locomotor CPGs (Song et al., 2016), whereas in neonatal mice, this is mediated by synaptic release of glutamate (Falgairolle et al., 2017).

\section{Commissurally projecting interneuronal populations}

Although locomotor rhythm generation and coordination of ipsilateral flexor and extensor motoneurons are reliant on ipsilaterally projecting interneurons, coordination of motoneurons on contralateral sides of the body depend on cells with commissural projections. Whereas this seems to be a logical assumption, it was formally demonstrated in the isolated spinal cord preparation in which appropriate left-right alternation was abolished after a midline hemisection (Kjaerulff and Kiehn, 1996). The V0 class of interneurons, which predominantly project commissural axons, are derived from Dbxl-expressing progenitors (Pierani et al., 2001) and were the first genetically defined interneuronal population identified to play a role in left-right alternation. Experiments assessing the function of these cells demonstrated that mice lacking Dbx1 interneurons displayed aberrant locomotor activity, with contralateral motoneuronal populations drifting in and out of phase with one another (Lanuza et al., 2004), indicating that the two sides were operating independently. Around the same time, it was demonstrated that the V0 population could be divided into a ventral subpopulation $\left(\mathrm{VO}_{\mathrm{V}}\right.$ cells $)$ that express the transcription factor Evx1 and a dorsal subpopulation ( $\mathrm{V} 0_{\mathrm{D}}$ cells) that do not express Evx1 but are derived from Pax7-expressing cells (Moran-Rivard et al., 2001; Pierani et al., 2001). In addition, a small population of cholinergic $\mathrm{V} 0$ cells ( $\mathrm{V} 0_{\mathrm{C}}$ interneurons) originate from the Evx1-expressing V0 neurons, make monosynaptic contact onto ipsilateral motoneurons, and are presumed to modulate their firing frequency (Zagoraiou et al., 2009). Initial work attributed the locomotor deficits in the Dbxl mutant mouse to the absence of the $\mathrm{V} 0_{\mathrm{D}}$ neurons because no aberrant locomotor phenotype was apparent in the Evx1-null mouse (Lanuza et al., 2004).

Subsequent experiments have demonstrated that $\mathrm{V} 0_{\mathrm{V}}$ and $\mathrm{V} 0_{\mathrm{D}}$ cells have complementary features and functions and both are involved in left-right alternation. The inhibitory $\mathrm{V} 0_{\mathrm{D}}$ cells coordinate left-right activity at slow locomotor speeds via monosynaptic connectivity onto contralateral motoneurons. As locomotor speed increases, the excitatory $\mathrm{V}_{\mathrm{V}}$ cells are recruited to regulate contralateral motor output and activate last-order inhibitory interneurons located close to their target motoneurons (Talpalar et al., 2013). It is interesting that elimination of V0 cells in the Dbxl mutants resulted in the left and right sides acting independently of one another (Lanuza et al., 2004), whereas deletion of the entire $\mathrm{V} 0$ population (or $\mathrm{V}_{\mathrm{V}}$ or $\mathrm{V} 0_{\mathrm{D}}$ cells alone) resulted in complete synchrony between the left and right sides (seen as hopping in the adult animal; Talpalar et al., 2013). These observations suggest that another group of neurons are involved in synchronizing activity on the left and right sides in the absence of the V0 cells.

The excitatory $\mathrm{V} 0_{\mathrm{V}}$ and inhibitory $\mathrm{V} 0_{\mathrm{D}}$ subsets are also present in the zebrafish and recent work in this species hints that there is more functional diversity in the V0 class than that which has been revealed in the mouse. Analysis of development of the $\mathrm{V}_{\mathrm{V}}$ class in zebrafish indicates that these commissural interneurons consist of three further subclasses that differentiate in a specific temporal order correlating with their axonal trajectories (Satou et al., 2012). Furthermore, a detailed study of the activity pattern of $\mathrm{V}_{\mathrm{V}}$ interneurons during locomotion in adult zebrafish has shown that this subset consists of two distinct cell types dependent on whether they display rhythmicity or not during locomotion. Rhythmic $\mathrm{V0}_{\mathrm{V}}$ interneurons were further subdivided into three subsets engaged sequentially, first at slow, then at intermediate, and finally at fast locomotor speeds (Björnfors et al., 2016). These data indicate that, along with motoneurons and V2a in- 


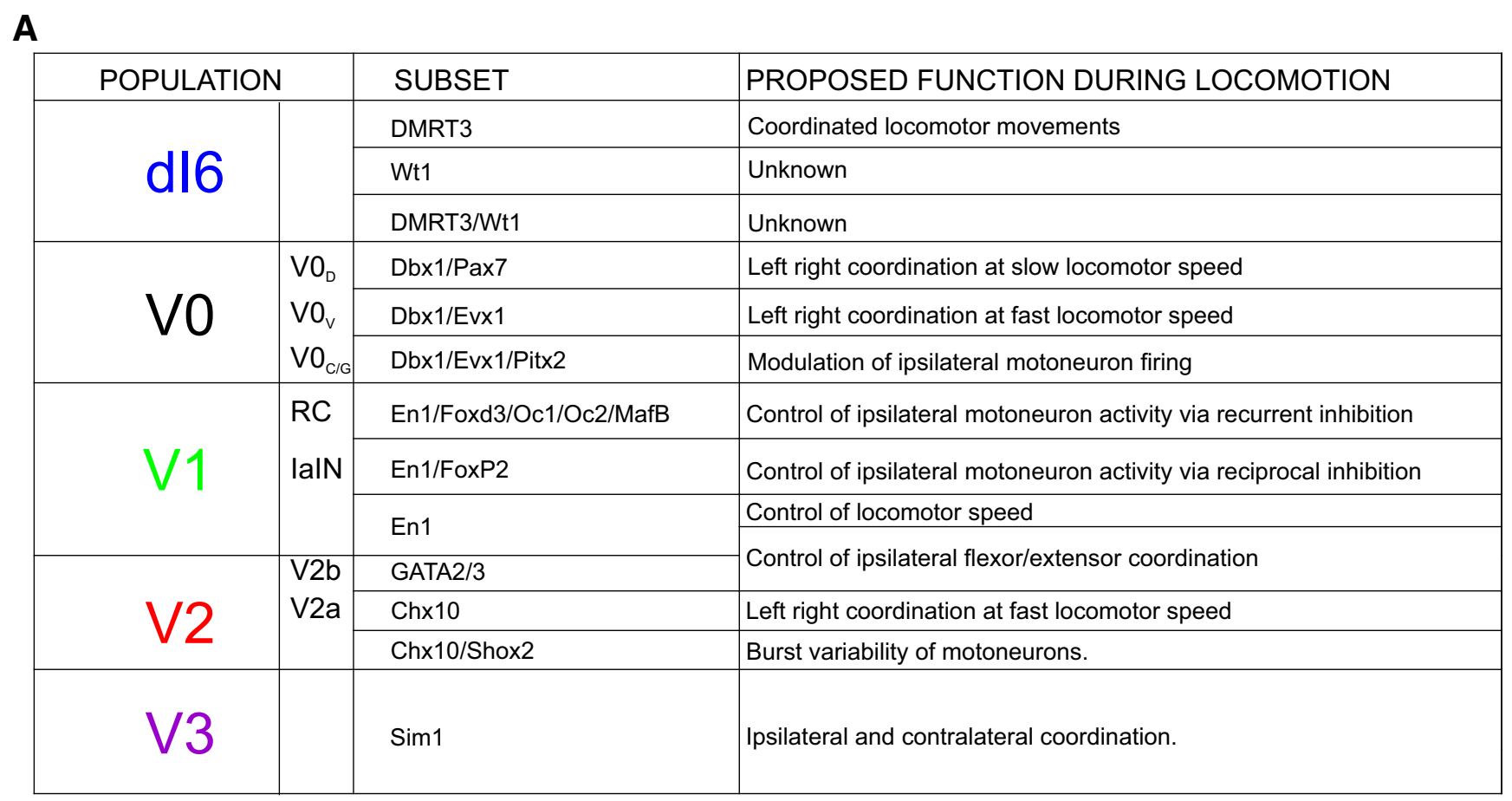

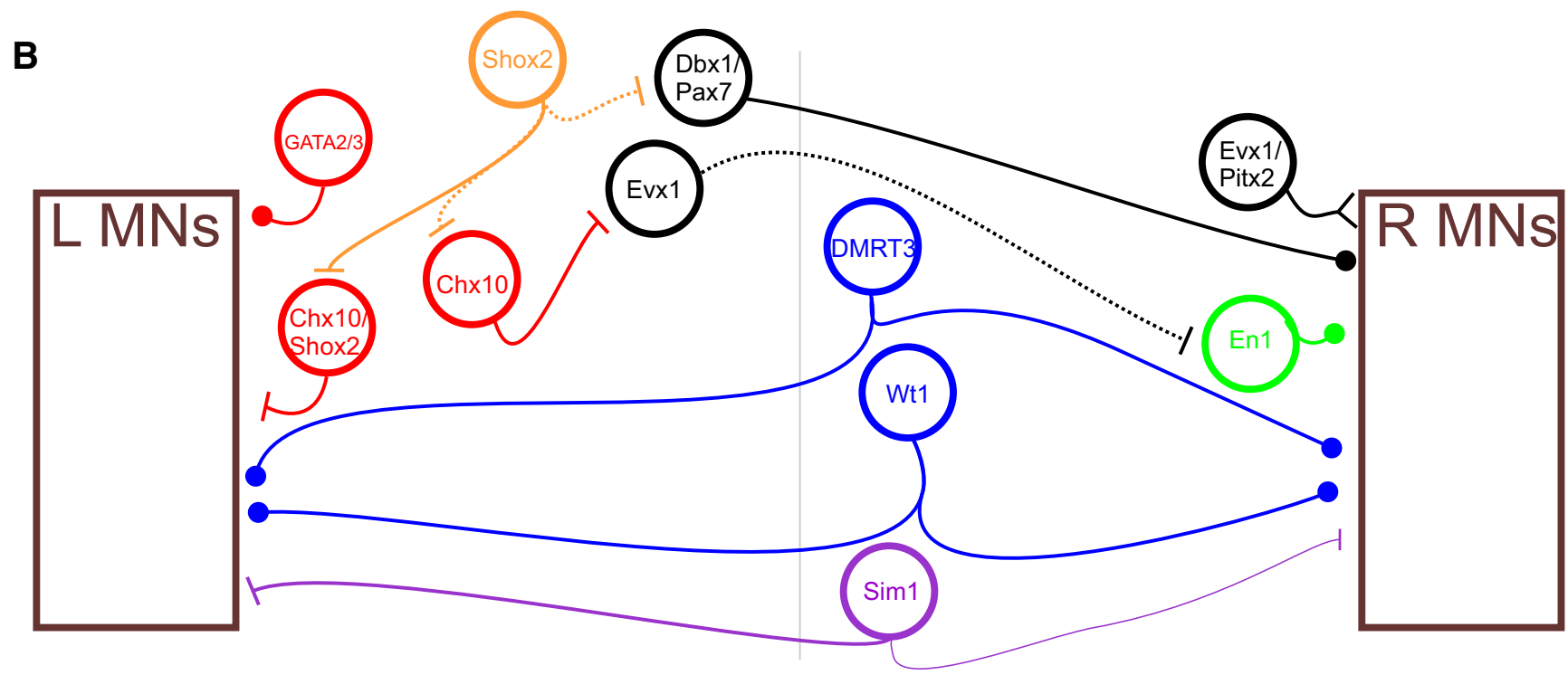

Figure 1. Genetic identity, locomotor function, and synaptic connectivity of molecularly defined subpopulations in the ventral spinal cord. $\boldsymbol{A}$, Table indicates the name of the cardinal populations, the subsets derived from each (including the defining transcription factors), and their function during locomotion. $\boldsymbol{B}$, Schematic summarizing initial experimental findings and predictions regarding synaptic connectivity of each population listed in $\boldsymbol{A}$. The non-V2a Shox $2+$ cells (orange) have also been included in $\boldsymbol{B}$. Synaptic connectivity that has been demonstrated experimentally is indicated

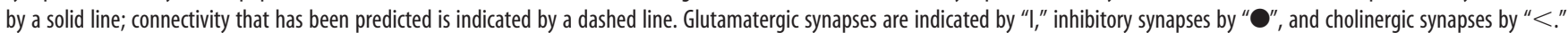
Motoneurons on the left (LMNs) and right (RMNs) are represented by the brown boxes on either side of the midline (gray horizontal line). Note that the connectivity presented here is not exhaustive.

terneurons (Ausborn et al., 2012; Ampatzis et al., 2014), the $\mathrm{V} 0_{\mathrm{V}}$ interneurons are also organized in a modular manner.

The dI6 interneurons originate from progenitor cells immediately dorsal to the V0 population and migrate to take up a position in the ventromedial spinal cord shortly before birth (Gross et al., 2002; Müller et al., 2002). To date, no single genetic marker has been identified that exclusively labels the entire dI6 population; however, they express the transcription factor Lbx1, a marker also expressed by other dorsal interneuronal populations. dI6 interneurons have been divided into at least three subsets based on postmitotic transcription factor expression: those that express Dmrt3, those that express WT1, and those that express both Dmrt3 and WT1 (Andersson et al., 2012). Although we have included them here as a commissurally projecting population, the Dmrt3+ and Wt1 + subsets have been shown to project both ipsilateral and contralateral axons and make contact onto motoneurons (Andersson et al., 2012). Whole-cell recordings from dI6 interneurons have indicated that a majority of these cells are rhythmically active during locomotion (Dyck et al., 2012); however, only the Dmrt3 + subset have had their function assessed. In the isolated spinal cord preparation Dmrt3 mutant mice displayed irregular bursting on either side of the spinal cord, which led to the conclusion that this subset of dI6 cells is required for the development of a coordinated locomotor network (Andersson et al., 2012). This hypothesis was supported by data collected from horses with a naturally occurring Dmrt3 mutation. 
Analysis of their locomotor pattern indicated that these animals were capable of alternate gaits such as pacing, which require atypical coordination between motor pools both ipsilaterally and contralaterally (Andersson et al., 2012).

The V3 cells are a group of excitatory commissural interneurons that emerge from the most ventral Nkx2.2-expressing progenitor domain of the neural tube and express the transcription factor Sim1 postmitotically (Zhang et al., 2008). Based on initial anatomical findings, the V3 interneurons seem to be a highly heterogeneous population. These cells are broadly distributed along the dorsal-ventral and rostral-caudal axes in the postnatal spinal cord and are found, not only in laminae VII and VIII, where most ventral commissural neurons reside, but also in clusters in laminae IV and V of the deep dorsal horn in the lower thoracic and rostral lumbar segments (Zhang et al., 2008; Borowska et al., 2013; Blacklaws et al., 2015). Axonal projection of these cells are broadly distributed with V3 cells located in the ventral and intermediate regions of the spinal cord making monosynaptic connections onto contralateral motoneurons, as well as ventrally located interneurons on either side of the spinal cord (Blacklaws et al., 2015, Zhang et al., 2008).

Blocking synaptic transmission or acute suppression of V3 neuron excitability in the isolated mouse spinal cord preparation resulted in incoherent, weak rhythmic activity and asymmetric locomotor outputs on the left and rights sides. Acute silencing of V3 neurons in the lumbar region of freely moving adult mice caused most animals to display uneven gaits. Based on these data, it was suggested that V3 interneurons play important roles in limb coordination during locomotion (Zhang et al., 2008). Molecular markers expressed by V3 cells located in distinct regions are currently being investigated and their identification may reveal definable subsets within this population. This seems likely because the ventral and dorsal V3 neurons display distinctive physiological and morphological properties present at birth and are recruited in different patterns in running and swimming (Borowska et al., 2013, 2015).

The ipsilaterally and contralaterally projecting cell types described above are not an exhaustive list of neurons that may be involved in locomotor control. A small population of neurons located in lamina VIII/X of the spinal cord have been shown to express the transcription factor $\mathrm{Hb} 9$ and have been suggested to be involved in rhythm generation (Hinckley et al., 2005; Wilson et al., 2005; Kwan et al., 2009; Caldeira et al., 2017). In addition, a recent study found that late neurogenic events in the developing mouse spinal cord produce CSF-contacting neurons (CSF-cNs) called Kolmer-Agduhr cells, an intriguing cell type surrounding the central canal, which, like the V2b interneurons, express the transcriptions factor Gata3 (Petracca et al., 2016). Although the role of CSF-cNs in locomotor circuits of the mouse spinal cord remains to be determined, in zebrafish and lamprey, CSF-cNs have been shown to regulate swimming by projecting directly onto locomotor CPG neurons (Hubbard et al., 2016; Jalalvand et al., 2016).

\section{Summary}

The discovery that spinal neurons can be divided into a few genetically distinct populations led to excitement that key components of the locomotor CPGs could be characterized and defined functionally. Over the past couple of decades, significant progress has been made in this regard. We now have a good grasp on the interneuronal populations responsible for key functions such as left-right and flexor-extensor coordination and are beginning to clarify the synaptic connectivity of interneurons involved in these functions (Fig. 1). What is clear from the work thus far is that, despite this effective approach, the spinal locomotor circuitry remains a complex circuit to crack. Each parent population can be divided into several subpopulations based on either transcription factor expression, location in the spinal cord, and/or activity during locomotion. Furthermore, it is becoming increasingly evident that many functions may rely on, or can tap into, small subsets of several populations. This may be essential given the fact that the locomotor pattern must be flexible and respond to environmental cues with subtle modifications to its output.

Despite advances in our understanding of the locomotor CPGs, we must keep in mind that many challenges remain, particularly regarding identification of the molecularly defined subpopulations of spinal interneurons, their morphological and physiological properties, and their connectivity and functional roles during stepping. With the development of novel experimental approaches, our understanding of the structure and mechanism of function of the locomotor CPGs is sure to grow. High-throughput sequencing techniques (i.e., single-cell RNAseq) will facilitate the identification of neuronal subsets (Lein et al., 2017, Zeng and Sanes, 2017). Genetically modified versions of rabies viruses (Callaway and Luo, 2015) and advanced optogenetic methods (Adamantidis et al., 2015) will allow the connectivity of these populations to be mapped and may enable their physiological properties, including their specific firing patterns during locomotion, to be identified. In addition, molecular techniques are evolving to allow for the manipulation of neuronal activity and functional assessment of individual subpopulations in the adult during overground locomotion (Britz et al., 2015), providing further insight into potential roles during locomotor activity. Collectively, these experimental approaches provide optimism that increasingly effective means will become available to delineate interneuronal subpopulations and the manner in which they interact with one another to generate locomotor outputs.

\section{References}

Adamantidis A, et al. (2015) Optogenetics: 10 years after ChR2 in neuronsviews from the community. Nat Neurosci 18:1202-1212. CrossRef Medline

Alaynick WA, Jessell TM, Pfaff SL (2011) SnapShot: spinal cord development. Cell 146:178-178.e1. CrossRef Medline

Ampatzis K, Song J, Ausborn J, El Manira A (2013) Pattern of innervation and recruitment of different classes of motoneurons in adult zebrafish. J Neurosci 33:10875-10886. CrossRef Medline

Ampatzis K, Song J, Ausborn J, El Manira A (2014) Separate microcircuit modules of distinct v2a interneurons and motoneurons control the speed of locomotion. Neuron 83:934-943. CrossRef Medline

Andersson LS, et al. (2012) Mutations in DMRT3 affect locomotion in horses and spinal circuit function in mice. Nature 488:642-646. CrossRef Medline

Arber S (2012) Motor circuits in action: specification, connectivity, and function. Neuron 74:975-989. CrossRef Medline

Ausborn J, Mahmood R, El Manira A (2012) Decoding the rules of recruitment of excitatory interneurons in the adult zebrafish locomotor network. Proc Natl Acad Sci U S A 109:E3631-E3639. CrossRef Medline

Bellardita C, Kiehn O (2015) Phenotypic characterization of speed-associated gait changes in mice reveals modular organization of locomotor networks. Curr Biol 25:1426-1436. CrossRef Medline

Benito-Gonzalez A, Alvarez FJ (2012) Renshaw cells and Ia inhibitory interneurons are generated at different times from p1 progenitors and differentiate shortly after exiting the cell cycle. J Neurosci 32:1156-1170. CrossRef Medline

Bikoff JB, Gabitto MI, Rivard AF, Drobac E, Machado TA, Miri A, BrennerMorton S, Famojure E, Diaz C, Alvarez FJ, Mentis GZ, Jessell TM (2016) Spinal inhibitory interneuron diversity delineates variant motor microcircuits. Cell 165:207-219. CrossRef Medline

Björnfors ER, El Manira A (2016) Functional diversity of excitatory 
commissural interneurons in adult zebrafish. Elife 5:e18579. CrossRef Medline

Blacklaws J, Deska-Gauthier D, Jones CT, Petracca YL, Liu M, Zhang H, Fawcett JP, Glover JC, Lanuza GM, Zhang Y (2015) Sim1 is required for the migration and axonal projections of $\mathrm{V} 3$ interneurons in the developing mouse spinal cord. Dev Neurobiol 75:1003-1017. CrossRef Medline

Borowska J, Jones CT, Zhang H, Blacklaws J, Goulding M, Zhang Y (2013) Functional subpopulations of V3 interneurons in the mature mouse spinal cord. J Neurosci 33:18553-18565. CrossRef Medline

Britz O, Zhang J, Grossmann KS, Dyck J, Kim JC, Dymecki S, Gosgnach S, Goulding M (2015) A genetically defined asymmetry underlies the inhibitory control of flexor-extensor locomotor movements. Elife 4. CrossRef Medline

Burrill JD, Moran L, Goulding MD, Saueressig H (1997) PAX2 is expressed in multiple spinal cord interneurons, including a population of EN1+ interneurons that require PAX6 for their development. Development 124: 4493-4503. Medline

Caldeira V, Dougherty KJ, Borgius L, Kiehn O (2017) Spinal Hb9::Crederived excitatory interneurons contribute to rhythm generation in the mouse. Sci Rep 7:41369. CrossRef Medline

Callaway EM, Luo L (2015) Monosynaptic circuit tracing with glycoproteindeleted rabies viruses. J Neurosci 35:8979-8985. CrossRef Medline

Cangiano L, Grillner S (2005) Mechanisms of rhythm generation in a spinal locomotor network deprived of crossed connections: the lamprey hemicord. J Neurosci 25:923-935. CrossRef Medline

Catela C, Shin MM, Dasen JS (2015) Assembly and function of spinal circuits for motor control. Annu Rev Cell Dev Biol 31:669-698. CrossRef Medline

Cowley KC, Schmidt BJ (1997) Regional distribution of the locomotor pattern-generating network in the neonatal rat spinal cord. J Neurophysiol 77:247-259. Medline

Crone SA, Quinlan KA, Zagoraiou L, Droho S, Restrepo CE, Lundfald L, Endo T, Setlak J, Jessell TM, Kiehn O, Sharma K (2008) Genetic ablation of V2a ipsilateral interneurons disrupts left-right locomotor coordination in mammalian spinal cord. Neuron 60:70-83. CrossRef Medline

Crone SA, Zhong G, Harris-Warrick R, Sharma K (2009) In mice lacking V2a interneurons, gait depends on speed of locomotion. J Neurosci 29: 7098-7109. CrossRef Medline

Del Barrio MG, Bourane S, Grossmann K, Schüle R, Britsch S, O'Leary DD, Goulding M (2013) A transcription factor code defines nine sensory interneuron subtypes in the mechanosensory area of the spinal cord. PLoS One 8:e77928. CrossRef Medline

Dougherty KJ, Zagoraiou L, Satoh D, Rozani I, Doobar S, Arber S, Jessell TM, Kiehn O (2013) Locomotor rhythm generation linked to the output of spinal shox2 excitatory interneurons. Neuron 80:920-933. CrossRef Medline

Dyck J, Lanuza GM, Gosgnach S (2012) Functional characterization of dI6 interneurons in the neonatal mouse spinal cord. J Neurophysiol 107: 3256-3266. CrossRef Medline

Eklöf-Ljunggren E, Haupt S, Ausborn J, Dehnisch I, Uhlén P, Higashijima S, El Manira A (2012) Origin of excitation underlying locomotion in the spinal circuit of zebrafish. Proc Natl Acad Sci U S A 109:5511-5516. CrossRef Medline

El Manira A (2014) Dynamics and plasticity of spinal locomotor circuits. Curr Opin Neurobiol 29:133-141. CrossRef Medline

Enjin A, Perry S, Hilscher MM, Nagaraja C, Larhammar M, Gezelius H, Eriksson A, Leão KE, Kullander K (2017) Developmental disruption of recurrent inhibitory feedback results in compensatory adaptation in the renshaw cell-motor neuron circuit. J Neurosci 37:5634-5647. CrossRef Medline

Falgairolle M, Puhl JG, Pujala A, Liu W, O’Donovan MJ (2017) Motoneurons regulate the central pattern generator during drug-induced locomotorlike activity in the neonatal mouse. Elife 6: pii: e26622. CrossRef Medline

Gabitto MI, Pakman A, Bikoff JB, Abbott LF, Jessell TM, Paninski L (2016) Bayesian sparse regression analysis documents the diversity of spinal inhibitory interneurons. Cell 165:220-233. CrossRef Medline

Gabriel JP, Ausborn J, Ampatzis K, Mahmood R, Eklöf-Ljunggren E, El Manira A (2011) Principles governing recruitment of motoneurons during swimming in zebrafish. Nat Neurosci 14:93-99. CrossRef Medline

Gosgnach S, Lanuza GM, Butt SJ, Saueressig H, Zhang Y, Velasquez T, Riethmacher D, Callaway EM, Kiehn O, Goulding M (2006) V1 spinal neu- rons regulate the speed of vertebrate locomotor outputs. Nature 440:215219. CrossRef Medline

Goulding M (2009) Circuits controlling vertebrate locomotion: moving in a new direction. Nat Rev Neurosci 10:507-518. CrossRef Medline

Goulding M, Pfaff SL (2005) Development of circuits that generate simple rhythmic behaviors in vertebrates. Curr Opin Neurobiol 15:14-20. CrossRef Medline

Grillner S (2003) The motor infrastructure: from ion channels to neuronal networks. Nat Rev Neurosci 4:573-586. Medline

Grillner S, El Manira A (2015) The intrinsic operation of the networks that make us locomote. Curr Opin Neurobiol 31:244-249. CrossRef Medline

Grillner S, Jessell TM (2009) Measured motion: searching for simplicity in spinal locomotor networks. Curr Opin Neurobiol 19:572-586. CrossRef Medline

Grillner S, Wallén P (1985) Central pattern generators for locomotion, with special reference to vertebrates. Annu Rev Neurosci 8:233-261. CrossRef Medline

Grillner S, Ekeberg, El Manira A, Lansner A, Parker D, Tegnér J, Wallén P (1998) Intrinsic function of a neuronal network: a vertebrate central pattern generator. Brain Res Brain Res Rev 26:184-197. CrossRef Medline

Gross MK, Dottori M, Goulding M (2002) Lbxl specifies somatosensory association interneurons in the dorsal spinal cord. Neuron 34:535-549. CrossRef Medline

Higashijima S, Masino MA, Mandel G, Fetcho JR (2004) Engrailed-1 expression marks a primitive class of inhibitory spinal interneuron. J Neurosci 24:5827-5839. CrossRef Medline

Hinckley C, Seebach B, Ziskind-Conhaim L (2005) Distinct roles of glycinergic and GABAergic inhibition in coordinating locomotor-like rhythms in the neonatal mouse spinal cord. Neuroscience 131:745-758. CrossRef Medline

Hubbard JM, Böhm UL, Prendergast A, Tseng PB, Newman M, Stokes C, Wyart C (2016) Intraspinal sensory neurons provide powerful inhibition to motor circuits ensuring postural control during locomotion. Curr Biol 26:2841-2853. CrossRef Medline

Jalalvand E, Robertson B, Wallén P, Grillner S (2016) Ciliated neurons lining the central canal sense both fluid movement and $\mathrm{pH}$ through ASIC3. Nat Commun 7:10002. CrossRef Medline

Jankowska E (1992) Interneuronal relay in spinal pathways from proprioceptors. Prog Neurobiol 38:335-378. CrossRef Medline

Jankowska E (2001) Spinal interneuronal systems: identification, multifunctional character and reconfigurations in mammals. J Physiol 533:3140. CrossRef Medline

Jessell TM (2000) Neuronal specification in the spinal cord: inductive signals and transcriptional codes. Nat Rev Genet 1:20-29. CrossRef Medline

Joshi K, Lee S, Lee B, Lee JW, Lee SK (2009) LMO4 controls the balance between excitatory and inhibitory spinal V2 interneurons. Neuron 61: 839-851. CrossRef Medline

Kiehn O (2006) Locomotor circuits in the mammalian spinal cord. Annu Rev Neurosci 29:279-306. CrossRef Medline

Kiehn O (2016) Decoding the organization of spinal circuits that control locomotion. Nat Rev Neurosci 17:224-238. CrossRef Medline

Kimura Y, Okamura Y, Higashijima S (2006) alx, a zebrafish homolog of Chx10, marks ipsilateral descending excitatory interneurons that participate in the regulation of spinal locomotor circuits. J Neurosci 26:56845697. CrossRef Medline

Kimura Y, Satou C, Higashijima S (2008) V2a and V2b neurons are generated by the final divisions of pair-producing progenitors in the zebrafish spinal cord. Development 135:3001-3005. CrossRef Medline

Kjaerulff O, Kiehn O (1996) Distribution of networks generating and coordinating locomotor activity in the neonatal rat spinal cord in vitro: a lesion study. J Neurosci 16:5777-5794. Medline

Kwan AC, Dietz SB, Webb WW, Harris-Warrick RM (2009) Spatiotemporal dynamics of rhythmic spinal interneurons measured with two-photon calcium. J Neurosci 29:11601-11613. Medline

Kyriakatos A, Mahmood R, Ausborn J, Porres CP, Büschges A, El Manira A (2011) Initiation of locomotion in adult zebrafish. J Neurosci 31:84228431. CrossRef Medline

Lanuza GM, Gosgnach S, Pierani A, Jessell TM, Goulding M (2004) Genetic identification of spinal interneurons that coordinate left-right locomotor activity necessary for walking movements. Neuron 42:375-386. CrossRef Medline

Lein ES, Belgard TG, Hawrylycz M, Molnár Z (2017) Transcriptomic per- 
spectives on neocortical structure, development, evolution, and disease. Annu Rev Neurosci.; 40:629-652.

Lemieux M, Josset N, Roussel M, Couraud S, Bretzner F (2016) Speeddependent modulation of the locomotor behavior in adult mice reveals attractor and transitional gaits. Front Neurosci 10:42. CrossRef Medline

Li S, Misra K, Matise MP, Xiang M (2005) Foxn4 acts synergistically with Mash1 to specify subtype identity of V2 interneurons in the spinal cord. Proc Natl Acad Sci U S A 102:10688-10693. CrossRef Medline

Li WC, Higashijima S, Parry DM, Roberts A, Soffe SR (2004) Primitive roles for inhibitory interneurons in developing frog spinal cord. J Neurosci 24:5840-5848. CrossRef Medline

Ljunggren EE, Haupt S, Ausborn J, Ampatzis K, El Manira A (2014) Optogenetic activation of excitatory premotor interneurons is sufficient to generate coordinated locomotor activity in larval zebrafish. J Neurosci 34:134-139. CrossRef Medline

Lu DC, Niu T, Alaynick WA (2015) Molecular and cellular development of spinal cord locomotor circuitry. Front Mol Neurosci 8:25. CrossRef Medline

Lundfald L, Restrepo CE, Butt SJ, Peng CY, Droho S, Endo T, Zeilhofer HU, Sharma K, Kiehn O (2007) Phenotype of V2-derived interneurons and their relationship to the axon guidance molecule EphA4 in the developing mouse spinal cord. Eur J Neurosci 26:2989-3002. CrossRef Medline

McCrea DA, Pratt CA, Jordan LM (1980) Renshaw cell activity and recurrent effects on motoneurons during fictive locomotion. J Neurophysiol 44:475-488. Medline

McLean DL, Fetcho JR (2009) Spinal interneurons differentiate sequentially from those driving the fastest swimming movements in larval zebrafish to those driving the slowest ones. J Neurosci 29:13566-13577. CrossRef Medline

McLean DL, Masino MA, Koh IY, Lindquist WB, Fetcho JR (2008) Continuous shifts in the active set of spinal interneurons during changes in locomotor speed. Nat Neurosci 11:1419-1429. CrossRef Medline

Moran-Rivard L, Kagawa T, Saueressig H, Gross MK, Burrill J, Goulding M (2001) Evx1 is a postmitotic determinant of V0 interneuron identity in the spinal cord. Neuron 29:385-399. CrossRef Medline

Moult PR, Cottrell GA, Li WC (2013) Fast silencing reveals a lost role for reciprocal inhibition in locomotion. Neuron 77:129-140. CrossRef Medline

Müller T, Brohmann H, Pierani A, Heppenstall PA, Lewin GR, Jessell TM, Birchmeier C (2002) The homeodomain factor Lbx1 distinguishes two major programs of neuronal differentiation in the dorsal spinal cord. Neuron 34:551-562. CrossRef Medline

Peng CY, Yajima H, Burns CE, Zon LI, Sisodia SS, Pfaff SL, Sharma K (2007) Notch and MAML signaling drives Scl-dependent interneuron diversity in the spinal cord. Neuron 53:813-827. CrossRef Medline

Petracca YL, Sartoretti MM, Di Bella DJ, Marin-Burgin A, Carcagno AL, Schinder AF, Lanuza GM (2016) The late and dual origin of cerebrospinal fluid-contacting neurons in the mouse spinal cord. Development 143: 880-891. CrossRef Medline

Pierani A, Moran-Rivard L, Sunshine MJ, Littman DR, Goulding M, Jessell TM (2001) Control of interneuron fate in the developing spinal cord by the progenitor homeodomain protein Dbx1. Neuron 29:367-384. CrossRef Medline

Pratt CA, Jordan LM (1980) Recurrent inhibition of motoneurons in decerebrate cats during controlled treadmill locomotion. J Neurophysiol 44: 489-500. Medline

Roberts A, Li WC, Soffe SR (2010) How neurons generate behavior in a hatchling amphibian tadpole: an outline. Front Behav Neurosci 4:16. CrossRef Medline

Sapir T, Geiman EJ, Wang Z, Velasquez T, Mitsui S, Yoshihara Y, Frank E, Alvarez FJ, Goulding M (2004) Pax6 and engrailed 1 regulate two distinct aspects of renshaw cell development. J Neurosci 24:1255-1264. CrossRef Medline

Satou C, Kimura Y, Higashijima S (2012) Generation of multiple classes of V0 neurons in zebrafish spinal cord: progenitor heterogeneity and temporal control of neuronal diversity. J Neurosci 32:1771-1783. CrossRef Medline

Saueressig H, Burrill J, Goulding M (1999) Engrailed-1 and netrin-1 regulate axon pathfinding by association interneurons that project to motor neurons. Development 126:4201-4212. Medline

Song J, Ampatzis K, Björnfors ER, El Manira A (2016) Motor neurons control locomotor circuit function retrogradely via gap junctions. Nature 529:399-402. CrossRef Medline

Stam FJ, Hendricks TJ, Zhang J, Geiman EJ, Francius C, Labosky PA, Clotman F, Goulding M (2012) Renshaw cell interneuron specialization is controlled by a temporally restricted transcription factor program. Development 139:179-190. CrossRef Medline

Talpalar AE, Bouvier J, Borgius L, Fortin G, Pierani A, Kiehn O (2013) Dualmode operation of neuronal networks involved in left-right alternation. Nature 500:85-88. CrossRef Medline

Tripodi M, Arber S (2012) Regulation of motor circuit assembly by spatial and temporal mechanisms. Curr Opin Neurobiol 22:615-623. CrossRef Medline

Wilson JM, Hartley R, Maxwell DJ, Todd AJ, Lieberam I, Kaltschmidt JA, Yoshida Y, Jessell TM, Brownstone RM (2005) Conditional rhythmicity of ventral spinal interneurons defined by expression of the $\mathrm{Hb} 9$ homeodomain protein. J Neurosci 25:5710-5719. CrossRef Medline

Zagoraiou L, Akay T, Martin JF, Brownstone RM, Jessell TM, Miles GB (2009) A cluster of cholinergic premotor interneurons modulates mouse locomotor activity. Neuron 64:645-662. CrossRef Medline

Zeng H, Sanes JR (2017) Neuronal cell-type classification: challenges, opportunities and the path forward. Nat Rev Neurosci 18:530-546. CrossRef Medline

Zhang J, Lanuza GM, Britz O, Wang Z, Siembab VC, Zhang Y, Velasquez T, Alvarez FJ, Frank E, Goulding M (2014) V1 and v2b interneurons secure the alternating flexor-extensor motor activity mice require for limbed locomotion. Neuron 82:138-150. CrossRef Medline

Zhang Y, Narayan S, Geiman E, Lanuza GM, Velasquez T, Shanks B, Akay T, Dyck J, Pearson K, Gosgnach S, Fan CM, Goulding M (2008) V3 spinal neurons establish a robust and balanced locomotor rhythm during walking. Neuron 60:84-96. CrossRef Medline 